\title{
Prevalence of Neural Tube Defects: Moroccan Study 2008-2011
}

\author{
Mohammed Amine Radouani1,2*, Naima Chahid $12^{*}$, Loubna Benmiloud1,2, Leila El Ammari3, \\ Aicha Kharbach ${ }^{1,2}$, Larbi Rjimati ${ }^{3}$, Laila Acharrai ${ }^{3}$, Khalid Lahlou ${ }^{3}$, Hassan Aguenaou4, \\ Amina Barkat ${ }^{1,2}$ \\ ${ }^{1}$ Department of Medicine and Neonatal Resuscitation, National Center for Neonatology and Nutrition, Rabat, \\ Morocco \\ ${ }^{2}$ Faculté de Medicine et de Pharmacie de Rabat, Université Mohammed V de Rabat, Rabat, Morocco \\ ${ }^{3}$ Population Department, Ministry of Health, Rabat, Morocco \\ ${ }^{4}$ Joint Research Unit in Nutrition and Food URAC 39, (Ibn Tofaïl University-CNESTEN), Regional Designated \\ Center of Nutrition Associated with AFRA/IAEA, Kénitra, Morocco \\ Email: barakatamina@yahoo.fr, dr.med.radouani@gmail.com
}

Received 19 July 2015; accepted 6 September 2015; published 9 September 2015

Copyright (C) 2015 by authors and Scientific Research Publishing Inc.

This work is licensed under the Creative Commons Attribution International License (CC BY). http://creativecommons.org/licenses/by/4.0/

(c) (i) Open Access

\section{Abstract}

Background: Neural tube defects have a considerable importance because they can be prevented by supplementing Folic acid \& Vitamin B12 during periconceptional period and fortification of staple foods. In Morocco, the Ministry of Health launched a national program for fortification of flour with folic acid. Our goal should be to evaluate the prevalence of neural tube defects after fortification. Description: This is a retrospective descriptive at the National Reference Centre for Nutrition and Neonatology of the Children's Hospital of Rabat over 4 years. Data were identified from the registry of congenital malformations held at the perinatology unit. Results: During the 4 years, 674 congenital malformations were identified. The neural tube defects NTDs account for $11.9 \%$. Their annual prevalence decreased significantly from 21.78 in 2008 to 12.1 per 10,000 total births in 2011. The most common form was anencephaly $(60 \%)$. Neural tube defects were isolated in $85 \%$ of cases and associated with other malformations in $15 \%$ of cases. $49.4 \%$ of infants with neural tube defects were female and $\mathbf{5 0 . 6 \%}$ were male. Perinatal mortality in newborns with neural tube defects was $63.8 \%$ versus $25.2 \%$ in malformed newborns without neural tube defects. Conclusions: The neural tube defects seem to be common in our context. Permanent epidemiological surveillance is needed to determine the true prevalence at the national as well as its temporal trends level.

\section{Keywords}

Neural Tube Defects, Anencephaly, Spina Bifida, Folic Acid, Prevalence

\footnotetext{
*These two authors have equal contribution.

How to cite this paper: Radouani, M.A., Chahid, N., Benmiloud, L., El Ammari, L., Kharbach, A., Rjimati, L., Acharrai, L., Lahlou, K., Aguenaou, H. and Barkat, A. (2015) Prevalence of Neural Tube Defects: Moroccan Study 2008-2011. Open Journal of Pediatrics, 5, 248-255. http://dx.doi.org/10.4236/ojped.2015.53038
} 


\section{Background}

The term "Neural tube defects" means a group of birth defects resulting from defective closure of the neural tube during embryogenesis, about 25 - 27 days after conception [1]. This accident can occur at any level of the neural plate, the cephalic end to the caudal end, and to a variable extent. This results in abnormalities of the meninges, the bony structures (vertebrae or skull), and integument compared with a variable impact on the nervous tissue [2]. These malformations are usually divided into cephalic and spinal forms. They include anencephaly, spina bifida and encephalocele [3]. The importance of this type of malformations due to both morbidity and mortality they cause and the opportunities that exist to control the appearance by means of primary prevention. There are two possibilities for this prevention: systematic drug supplementation and fortification of staple foods. Means neither is sufficient in itself and it is probably a combination of the two that will prevent the neural tube defects [4].

Reddi Rani, Manjula in their clinical and USG study of evaluation of 100 cases of polyhydramnios observed 40 babies with congenital anomalies, and 21 cases had craniospinal CNS anomalies [52.5\%]. NTDs were 143 [14\%] [5]. Balakumar K. studied 30,030 singleton 941 weeks gestation, ultrasonography done and the analysis reported as 2.59\% had major foetal anomalies, 336 cases [39.20\%] had CNS anomalies, NTDs were 250 [0.83\%] [6]. Sania Tanveer et al. reported study of 3310 deliveries and 46 cases with NTDs giving incidence of $1.39 \%$. Ghanashyam Das et al. [7] reported a rare occurence of a case of Dizygotic twin with meningomyelocele in both the 7 babies.

Ministry of Health in Morrocco, with the support of its partners, has launched a national flour fortification with folic acid and conducted a pilot experience at 20 public health centers and 4 hospital departments. The results reported an estimated 33.6 per 10,000 live births before starting the fortification program in Morocco [4].

The purpose of this study was to evaluate the prevalence of NTDs changes at the National Reference Centre for Nutrition and Neonatology of the Children's Hospital of Rabat during the years 2008, 2009, 2010 and 2011, during which the fortified flour with folic acid is on the Moroccan market.

\section{Construction and Content}

\subsection{Data Source}

This is a unicentric retrospective descriptive study at the National Reference Centre for Nutrition and Neonatology of the Children's Hospital of Rabat over a period of 4 years between 1 January 2008 and 31 December 2011 data were recorded from the register of Congenital Malformations held at the perinatology unit. The sex of the newborn, its viability at birth and the type of malformation.

Case definition: All defects were taken into account whether single or multiple. Malformations were classified according to the categories proposed by the standardized classification of European surveillance of congenital anomalies. These categories are: nervous system, eye, ear, face, neck, heart, respiratory system, oral facial clefts, the digestive system, abdominal wall, the urogenital system, members and anomalies chromosome (EUROCAT: www.eurocat-network.eu).

Newborn with malformation syndromes were classified polymalformation. Newborns whose specific type of malformation was not mentioned on the record or having a defect that is not part of the categories listed above were classified in the category unspecified malformation or other. NTDs are classified in the category of malformations of the nervous system and include cases of anencephaly, spina bifida and isolated or associated with other malformations of the nervous system malformations classified in other categories encephalocele.

The prevalence of congenital malformations of all types refers to the number of newborns with malformations among births (live births and stillbirths), divided by the total number of births. The prevalence of NTDs in turn refers to the number of newborns with NTDs among births (live births and stillbirths), divided by the total number of births.

Immediate perinatal mortality in infants malformed corresponds to the number of stillbirths and deaths in the delivery room with a malformation based on the total number of malformed newborns.

\subsection{Statistical Analysis}

The statistical study was performed using SPSS Version 17.0 software. Data were expressed as percentages and comparisons were performed by the Chi ${ }^{2}$ test $\left(\chi^{2}\right)$ of Pearson. A p value less than 0.05 was used as the threshold 
for statistical significance.

\section{Results}

- Birth defects of all types

The number of total births registered during the 4 years was 60,017: 13,768 in 2008, 14,569 in 2009, 15,152 in 2010 and 16,528 in 2011; 492 malformed infants were identified.

The annual prevalence decreased from 98.77 per 10,000 total births in 2008 to 80.46 in 2011. This decrease is not statistically significant $(p=0.07$ ) (Figure 1). $54.5 \%$ of infants were male, $42.1 \%$ female and $3.4 \%$ of unknown sex. $13.4 \%$ of infants were stillborn. Early neonatal deaths were recorded in $18.1 \%$ of cases. The most common malformations were neurological malformations (20\%) and first NTDs (11.9\%) (Table 1).

- NTDs

\subsection{Prevalence}

The annual prevalence of NTDs has declined significantly between 2008 and $2011(\mathrm{p}=0.01)$ (Figure 2). That of anencephaly increased from 15.25 in 2008 to 7.86 per 10,000 total births in 2011 (Figure 3). This decrease was statistically significant $(p<0.01)$. About spina bifida, prevalence decreased non significantly between 2008 and 2011 ( $p=0.7$ ) (Figure 4). A single case of encephalocele was recorded in 2008.

\subsection{Distribution of NTDs by Type}

Eighty neural tube defects were identified. The most common form was anencephaly (60\%). Spina bifida was found in $38.8 \%$ of cases.

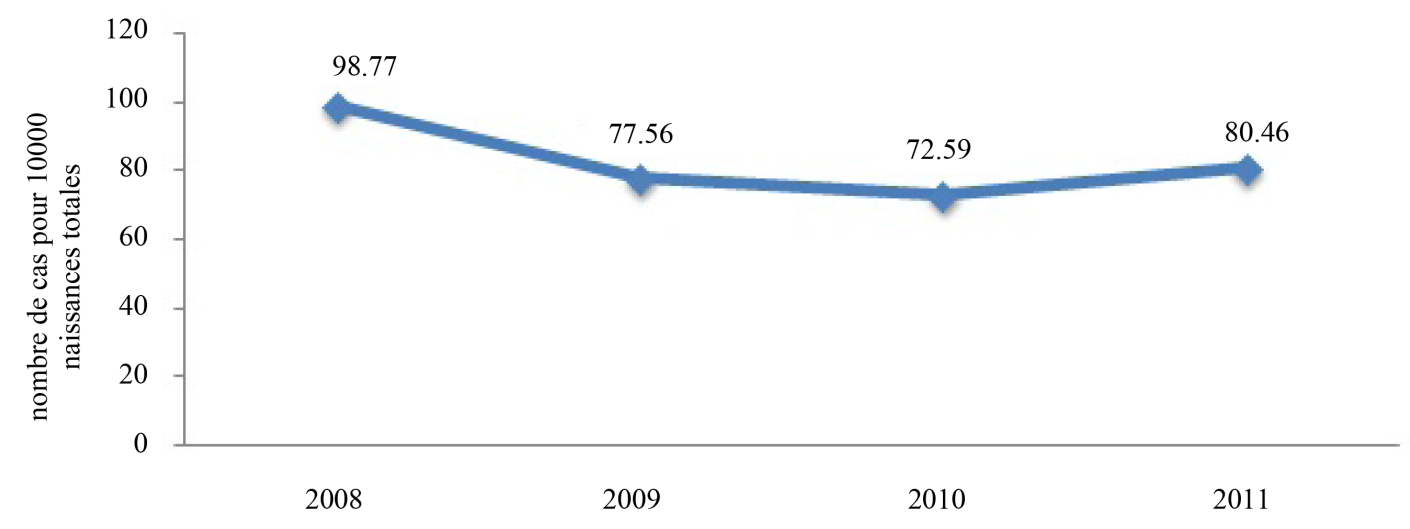

Figure 1. Prevalence of congenital malformations 2008-2011.

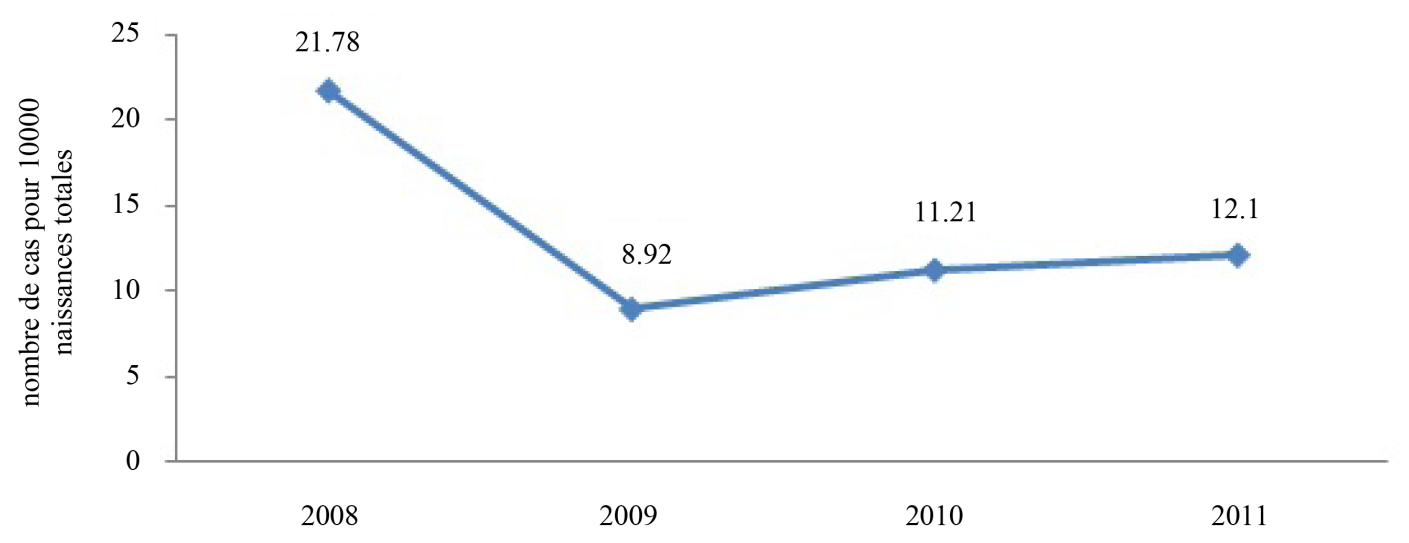

Figure 2. Prevalence of NTDs 2008-2011. 


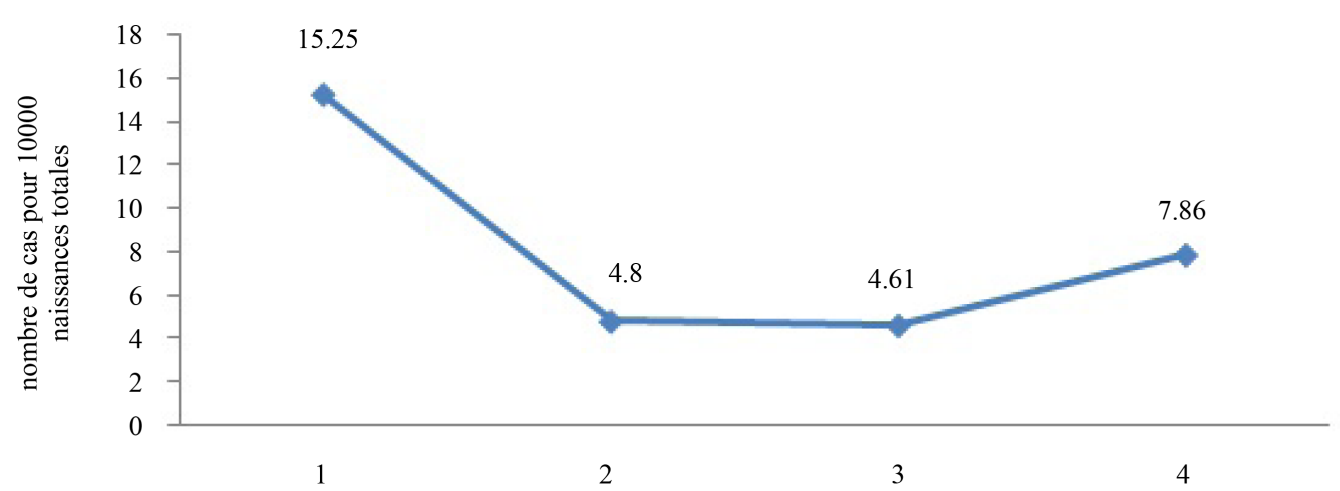

Figure 3. Prevalence of anencephaly 2008-2011.

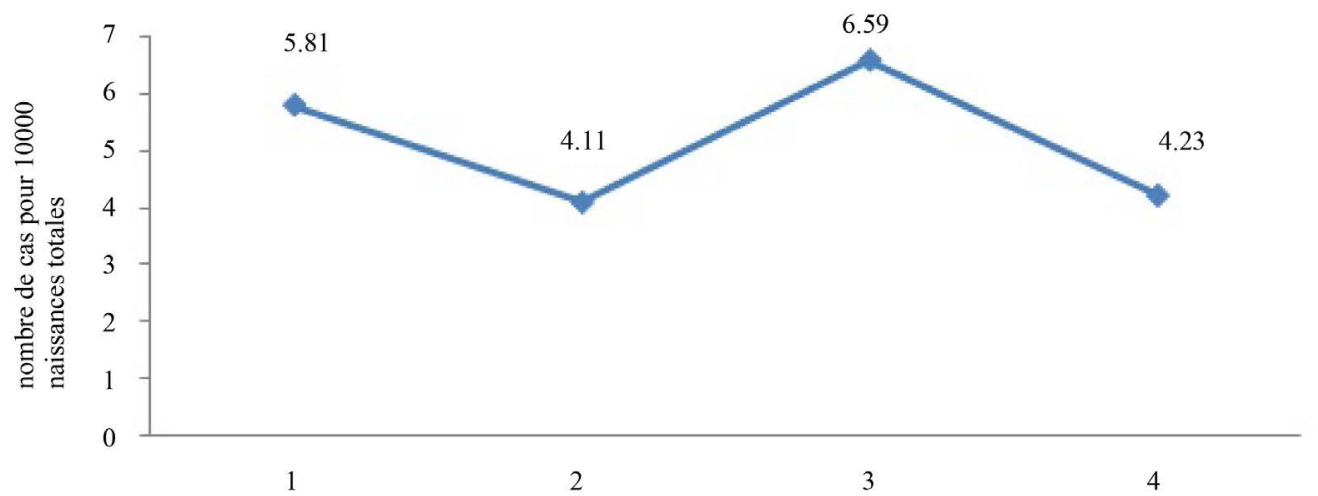

Figure 4. Prevalence of spina bifida 2008-2011.

Table 1. Types of NTDs.

\begin{tabular}{cccccc}
\hline Malformation & 2008 & 2009 & 2010 & 2011 & Total \\
\hline Neurological & 50 & 19 & 31 & 33 & $133(19.7 \%)$ \\
Neural tube & 30 & 13 & 17 & 20 & $80(11.9 \%)$ \\
Microcephaly & 0 & 1 & 1 & 0 & $2(0.3 \%)$ \\
Hydrocephaly & 17 & 4 & 11 & 12 & $44(6.5 \%)$ \\
Others & 3 & 1 & 2 & 1 & $7(1 \%)$ \\
Eye & 1 & 1 & 1 & 0 & $3(0.4 \%)$ \\
Ear, face & 4 & 4 & 3 & 3 & $14(2 \%)$ \\
Orofacial clefts & 9 & 3 & 9 & 12 & $33(4.9 \%)$ \\
Digestive & 5 & 0 & 3 & 0 & $8(1.2 \%)$ \\
Abdominal wall & 8 & 3 & 5 & 2 & $18(2.7 \%)$ \\
Respiratory & 1 & 0 & 2 & 0 & $3(0.4 \%)$ \\
Cardiac & 1 & 0 & 1 & 0 & $2(0.3 \%)$ \\
Urogenital & 14 & 14 & 10 & 14 & $52(7.7 \%)$ \\
Membres & 24 & 28 & 22 & 25 & $99(14.7 \%)$ \\
Genetic & 16 & 17 & 10 & 16 & $59(8.8 \%)$ \\
Polymalformation & 17 & 19 & 23 & 28 & $87(13 \%)$ \\
Others & 8 & 10 & 1 & 11 & $30(4.5 \%)$ \\
Total & 208 & 137 & 152 & 177 & 674
\end{tabular}




\subsection{Distribution of NTDs by Isolated or Associated Character with Other Abnormalities}

NTDs were isolated in $85 \%$ of cases and associated with other malformations in $15 \%$ of cases. Of the 48 children with anencephaly, 3 had other malformations polymalformation in 2 children and ambiguity and clubfoot in children. Spina bifida was isolated from 22 newborns and associated with other malformations in 9 neonates (Table 2).

\subsection{Sex Distribution}

49.4\% of infants with neural tube defects were female and 50.6\% male. The difference is not significant ( $\mathrm{p}=$ 0.26). $54.3 \%$ of anencephalic infants were female and $45.7 \%$ male. Statistically, the difference was not significant ( $p=0.12) .43 .9 \%$ of newborns with spina bifida were female and $56.7 \%$ male. The difference is not significant $(p=0.97)$. The only patient with an encephalocele is a boy.

\subsection{Immediate Perinatal Mortality}

Perinatal mortality in newborns with neural tube defects was $63.8 \%$ against $25.2 \%$ in newborns without malformed neural tube defects. The difference is statistically significant $(\mathrm{p}<0.01)$.

\section{Utility and Discussion}

Birth defects are the leading cause of infant mortality in developed countries [8] and they are among the five leading causes in many developing countries [9].

Malformations of the central nervous system are the most common birth defects and NTDs constitute the greater part [2]. In our work, malformations of the nervous system are the most frequent and the first neural tube defects. NTDs are the result of a combination of environmental and genetic factors. Only nutritional factors are risk factors on which it is possible to influence [10].

Folate (vitamin B9) and vitamin B12 are very important in reducing the occurrences of NTDs [11]. Folate is required for the production and maintenance of new cells, for DNA synthesis and RNA synthesis. Folate is needed to carry one carbon groups for methylation and nucleic acid synthesis. It has been hypothesized that the early human embryo may be particularly vulnerable to folate deficiency due to differences of the functional enzymes in this pathway during embryogenesis combined with high demand for post translational methylations

Table 2. Distribution of NTDs based on single or associated character.

\begin{tabular}{|c|c|}
\hline Anomalies & Number of cases \\
\hline Isolated NTD & $68(85 \%)$ \\
\hline Anencephaly & 45 \\
\hline Spina bifida & 22 \\
\hline Encephalocele & 1 \\
\hline Associeted NTD & $12(15 \%)$ \\
\hline Spina bifida + hydrocephaly & 4 \\
\hline Spina bifida + macrocrania & 1 \\
\hline Spina bifida, cleft lip and palate, malformation of members, cardiopathy & 1 \\
\hline Spina bifida, club foot, trisomic facies & 1 \\
\hline Spina bifida + club foot & 1 \\
\hline Anencephaly + polymalformation & 2 \\
\hline Anencephaly, trouble of sex differences, club foot & 1 \\
\hline Spina bifida + polymalformation & 1 \\
\hline
\end{tabular}

Neural tube defects (NTDs). 
of the cytoskeleton in neural cells during neural tube closure [11].

The association seen between reduced neural tube defects and folic acid supplementation is due to a gene-environment interaction such as venerability caused by the C677T Methylenetetrahydro folate reductase (MTHFR) variant. Supplementing folic acid during pregnancy reduces the prevalence of NTDs by not exposing this otherwise sub-clinical mutation to aggravating conditions [12].

Other potential causes can include folate antimetabolites (such as methotrexate), maternal diabetes, maternal obesity, mycotoxins in contaminated corn meal, arsenic, hyperthermia in early development, and radiation [13]. Studies have shown that both maternal cigarette smoking and maternal exposure to secondhand smoke increased the risk for neural tube defects in offspring. A mechanism by which maternal exposure to cigarette smoke could increase NTD risk in offspring is suggested by several studies that show an association between cigarette smoking and elevations of homocysteine levels. The study suggests that cigarette smoke, including secondhand exposure, is not only hazardous to the mother, but may also interfere with neural tube closure in the developing embryo [14].

All of the above may act by interference with some aspect of normal folic acid metabolism and folate linked methylation related cellular processes as there are multiple genes of this type associated with neural tube defects.

Our cohort allowed having an annual incidence of occurrence of TND based solely on the parturients s prenatal care regardless of other known risk factors in the literature.

Many interventional and observational studies have shown that $50 \%$ to $70 \%$ of NTDs can be prevented by supplementing Folic acid \& Vitamin B12 during periconceptional period [15]. These data led, in 1992, health authorities in several countries to advocate routine supplementation for all women in the periconceptional period, using synthetic folic acid at a daily dose of $400 \mathrm{mcg}$ orally in the general population and $4 \mathrm{mg}$ in women who have had one child with NTD [16]. Today, approximately 40 countries have mandated the fortification of flour with folic acid [9]. More recently several studies on the effects of folic acid fortification have been published [16].

The protective effect was confirmed in several countries and regions studied and ranged from $16 \%$ to $78 \%$ [17]. Trough these data, Morocco has adopted a national program of fortification of flour with folic acid since 2007. Nevertheless, this strategy has not yet been assessed nationally.

At maternity care Souissi, the prevalence of neural tube defects has declined between 2008 and 2011 in a meaningful way. This decrease is mainly attributed to the decrease in prevalence of anencephaly which decreased 15.2520087 .86 in 2011. Although the relationship of cause and effect can not be inferred, the decrease prevalence of NTDs could be explained by the effect of fortification but also by improving prenatal diagnosis. However, the observed prevalence of NTDs remains high compared to other countries which have decided the systematic fortification of flour with folic acid as Chile 8.6 per 10,000 births [18] and Costa Rica 5.04 per 10,000 births [9]. This little be explained by geographic and ethnic variations that have been reported in the literature [2]-[19].

Anencephaly is the most common neural tube defects form. It represents $50 \%$ to $65 \%$ [20]. In our series, it was found in $60 \%$ of cases reported during the 4 years. NTDs are more common in newborns female [20]. This predominance is more pronounced for anencephalic infants [20]. In our series, a female predominance was observed in newborns with NTDs and in anencephalic infants, but the difference with malformed infants not having a neural tube defect is not significant.

The association of neural tube defects with other malformations has been reported in the literature in $20 \%$ of cases [8]. This was found in $15 \%$ of neonates in our series.

\section{Conclusion}

The TNDs are purveyors of high mortality and morbidity. They seem to be common in our context from the data of this work. Permanent epidemiological surveillance is needed to determine the true prevalence at the national as well as its time trend. It will also enable to evaluate strategies of health authorities concerning such defects. For this, the establishment of a national registry of NTDs is necessary. The participation of health actors whether it be general practitioners, gynecology obstetricians, paediatricians and midwives is essential.

\section{Acknowledgements}

To all the mothers and babies who contributed to the study. 


\section{Competing Interests}

The authors declare that there are no conflicts of interest and shall disclose any potential conflicts of interest in the future.

\section{Authors' Contributions}

Hajar Rhouda, N. Chahid, M.A. Radouani: Writing. L. Elammari, Aicha Kharbach, A. Rjimati, L. Acharaai, K. Lahlou: Collect data. Amina Barkat: Reading and correcting.

\section{Ethical Approval Statement}

Read and approved by the Ethics Committee of the Faculty of Medicine and Pharmacy of Rabat.

\section{References}

[1] Moore, K.L. and Persaud, T.V.N. (1998) The Developing Human. Clinically Oriented Embryology. WB Saunders Company, Toronto.

[2] Cabaret, A.S. (2004) Les malformations du tube neural: Ethiopathogénie et facteurs pronostiques: A partir de 83 cas du centre pluridisciplinaire du diagnostic prénatal de Rennes [Thèse]. Université de Rennes, Rennes.

[3] Elwood, M., Elwood, H. and Little, J. (1992) Epidemiology and Control of Neural Tube Defects. Oxford University Press, Oxford.

[4] Barkat, A., Elammari, L., Acharai, L., Rjimati, L., Mahfoudi, M., Zerrari, A., et al. (2009) Malformations en rapport avec un déficit en acide folique: De la notification à la prévention. Biosanté, 2, 13-17.

[5] Reddi Rani, M. (2003) Clinical and Ultrasonographic Evaluation of Polyhydramnios. The Journal of Obstetrics and Gynecology of India, 53, 145-148.

[6] Balakumar, K. (2007) Major Anatomical Fetal Anomalies in Northern Kerala. The Journal of Obstetrics and Gynecology of India, 57, 311-315.

[7] Das, G., Aggarwal, A. and Faridi. M.M.A. (2003) Dizygotic Twins with Myelomeningocele. Indian Journal of Paediatrics, 70, 265-267. http://dx.doi.org/10.1007/BF02725595

[8] Stevenson, R.E., Allen, W.P., Pai, G.S., Best, R., Seaver, L.H., Dean, J., et al. (2000) Decline in Prevalence of Neural Tube Defects in a High-Risk Region of the United States. Pediatrics, 106, 677-683. http://dx.doi.org/10.1542/peds.106.4.677

[9] Barboza Argüello, M.L. and Umaña Solís, L.M. (2011) Impacto de la fortificación de alimentos con ácido fólico en los defectos del tubo neural en Costa Rica. American Journal of Public Health, 30, 1-6.

[10] Wanat, S., Brazier, M., Boitte, F. and Lemay, C. (2005) Serum Levels of Vitamin B9 and B12 in Women with a Pregnancy Complicated by Neural Tube Defects. Immunology \& Cell Biology, 20, 28-31.

[11] Molloy, A.M., Kirke, P.N., Troendle, J.F., Burke, H., Sutton, M., Brody, L.C., Scott, J.M. and Mills, J.L. (2009) Maternal Vitamin B-12 Status and Risk of Neural Tube Defects in a Population with High Neural Tube Defect Prevalence and No Folic Acid Fortification. Pediatrics, 123, 917-923. http://dx.doi.org/10.1542/peds.2008-1173

[12] Yan, L.F., Zhao, L., Long, Y., Zou, P., Ji, G.X., Gu, A.H. and Zhao, P. (2012) Association of the Maternal MTHFR C677T Polymorphism with Susceptibility to Neural Tube Defects in Offsprings: Evidence from 25 Case-Control Studies. PLoS ONE, 7, e41689. http://dx.doi.org/10.1371/journal.pone.0041689

[13] Neural Tube Defects at eMedicine.

[14] Suarez, L., Felkner, M., Brender, J.D., Canfield, M. and Hendricks, K. (2008) Maternal Exposures to Cigarette Smoke, Alcohol, and Street Drugs and Neural Tube Defect Occurrence in Offspring. Maternal and Child Health Journal, 12, 394-401. http://dx.doi.org/10.1007/s10995-007-0251-y

[15] De Wals, P., Tairou, F., Ouakki, M. and Six, M. (2007) Impact de la politique d'enrichissement des farines par l'acide folique sur la fréquence des malformations congénitales au Québec. Direction des risques biologiques, environnementaux et occupationnels. Institut national de santé publique du Québec.

[16] Vidailhet, M., Bocquet, A., Bresson, J.L., Briend, A., Chouraqui, J.P., Dupont, C., et al. (2008) Prévention par l'acide folique des défauts de fermeture du tube neural: La question n’est toujours pas réglée. Archives de Pédiatrie, 15, 12231231. http://dx.doi.org/10.1016/j.arcped.2008.04.012

[17] Santos, L.M.P. and Pereira, M.Z. (2007) Efeito da fortifi cação com ácido fólico na redução dos defeitos do tubo neural. Cadernos de Saúde Pública, 23, 17-24. http://dx.doi.org/10.1590/S0102-311X2007000100003 
[18] Cortés, F., Mellado, C., Pardo, R.A., Villarroel, L.A. and Hertrampf, E. (2012) Wheat Flour Fortification with Folic Acid: Changes in Neural Tube Defects Rates in Chile. American Journal of Medical Genetics Part A, 158, 1885-1890. http://dx.doi.org/10.1002/ajmg.a.35430

[19] Zhu, J., Li, X.H., Wang, Y.P., Mu, D.Z., Dai, L., Zhou, G.X., et al. (2012) Prevalence of Neural Tube Defect Pregnancies in China and the Impact of Gestational Age of the Births from 2006 to 2008: A Hospital-Based Study. Journal of Maternal-Fetal and Neonatal Medicine, 25, 1730-1734. http://dx.doi.org/10.3109/14767058.2012.663022

[20] Himmetoglu, O., Tiras, M.B., Gursoy, R., Karabacak, O., Sahin, I. and Onan, A. (1996) The Incidence of Congenital Malformations in a Turkish Population. International Journal of Gynecology \& Obstetrics, 55, 117-121.

http://dx.doi.org/10.1016/S0020-7292(96)02743-9

\section{List of Abbreviations}

NTDs: Neural tube defects 